\title{
Parametric studies on the properties of geopolymer concrete
}

\author{
Karnati Vamsi Krishna ${ }^{*}$, Srinivasa Reddy $\mathrm{V}^{2}, S$ Shrihari ${ }^{3}$ and $C$ Rajashekar ${ }^{4}$ \\ ${ }^{1}$ M. Tech (Structural Engineering), Department of Civil Engineering, GRIET, Hyderabad, India. \\ ${ }^{2}$ Professor of Civil Engineering, GRIET, Hyderabad, India. \\ ${ }^{3}$ Professor of Civil Engineering, VJIT, Hyderabad, India. \\ ${ }^{4}$ Assistant Professor of Civil Engineering, JBIET, Hyderabad, India.
}

\begin{abstract}
In the current study, effect of Alkali Activator solution (AAS) / Fly ash (FA) ratios and various molarities of $\mathrm{NaOH}$ on the compressive strength of geopolymer concrete (GPC) is studied keeping $\mathrm{Na}_{2} \mathrm{SiO}_{3} / \mathrm{NaOH}=2.5$ and $\mathrm{SiO}_{2} / \mathrm{Na}_{2} \mathrm{O}=2.0$ optimal ratios constant. For $A A S / F A=4.0$ and $16 \mathrm{M} \mathrm{NaOH}$ combination yields better strength so this combination is chosed as optimal. From studies it is found that the optimum temperature for curing is $60^{\circ} \mathrm{C}$ and optimum period of curing is $24 \mathrm{~h}$ based on the compressive strengths achieved.
\end{abstract}

\section{Introduction}

Formation of Geopolymer binder has basic reaction mechanism in three stages

1. Dissolution of $\mathrm{Si}_{4}{ }^{+}$and $\mathrm{Al}_{3}{ }^{+}$ions from the fly ash and GGBS into $\mathrm{NaOH}$ solution

2. Hydrolysis or gelation

3. Condensation by $\mathrm{Na}_{2} \mathrm{SiO}_{3}$

After 3 stages of reaction, 3D networks of silicon-oxygenaluminum framework with silicon and aluminum tetrahedral linked in three directions by sharing all the oxygen atoms are formed.

\section{Materials and Mix Proportions}

From the past research conducted by V Srinivasa Reddy et al. it was reported that the $16 \mathrm{M} \mathrm{NaOH}$ gives maximum compressive strength. So $16 \mathrm{M} \mathrm{NaOH}$ is adopted for further study. Similarly based on past work done by the authors, $\mathrm{SiO}_{2} / \mathrm{Na}_{2} \mathrm{O}$ ratio of 2.0 is maintained in $\mathrm{Na}_{2} \mathrm{SiO}_{3}$ solution and molar ratio of $\mathrm{Na}_{2} \mathrm{SiO}_{3} / \mathrm{NaOH}=2.5$ by mass are adopted for further studies.

Materials used to develop geopolymer concrete mixes to study the the effect of temperature and period of heat curing is presented below:

- $16 \mathrm{M} \mathrm{NaOH}$

- $\mathrm{SiO}_{2} / \mathrm{Na}_{2} \mathrm{O}=2.0$
- $\mathrm{Na}_{2} \mathrm{SiO}_{3} / \mathrm{NaOH}=2.5$ by mass

- Fly Ash $=450 \mathrm{~kg} / \mathrm{m}^{3}$

- Alkali Activator solution (AAS) / Fly ash $=0.40$

- $\quad$ Fine aggregate $=505 \mathrm{~kg} / \mathrm{m}^{3}$

- $20 \mathrm{~mm}$ Coarse aggregate $=1246 \mathrm{~kg} / \mathrm{m}^{3}$

- $\quad$ Slump required $=100 \mathrm{~mm}$

- Heat Curing

- No superplasticizer used

Sodium hydroxide solution is prepared before $24 \mathrm{hrs}$. Sodium silicate solution and sodium hydroxide solutions are mixed before 30 minutes of concrete making. Rest period adopted is 0 days means kept in oven with moulds sealed, immediately after casting. Rest period is the period before keeping in oven for curing from the time of casting.

\section{Effect of Alkali Activator solution (AAS) / Fly ash (FA) ratio}

The below table presents the compressive strength of geopolymer concrete (GPC) mixes made with different ratios of AAS/FA ratios and various molarities of $\mathrm{NaOH}$. The adopted ratios for $\mathrm{Na}_{2} \mathrm{SiO}_{3} / \mathrm{NaOH}=2.5$ and $\mathrm{SiO}_{2} / \mathrm{Na}_{2} \mathrm{O}=2.0$ based on past research carried out by the authors. Geopolymer concrete mixes are oven cured at temperature $60^{\circ} \mathrm{C}$ for a period of $24 \mathrm{~h}$. Rest period is 0 days means kept in oven immediately after casting with moulds sealed.

\footnotetext{
${ }^{*}$ Corresponding author: karnati.vamsi456@gmail.com
} 
Table 1. Effect of Alkali Activator solution (AAS) / Fly ash (FA) ratio on compressive strength for various GPC mixes made with different molarities of $\mathrm{NaOH}$

\begin{tabular}{|c|c|c|c|c|c|c|}
\hline \multirow{3}{*}{ AAS/FA ratio } & \multicolumn{7}{|c|}{$\mathrm{Na}_{2} \mathrm{SiO}_{3} / \mathrm{NaOH}=2.5 ; \mathrm{SiO}_{2} / \mathrm{Na}_{2} \mathrm{O}=2.0$} \\
\cline { 2 - 7 } & \multicolumn{7}{|c|}{$\mathrm{NaOH}$ Molarity } & $14 \mathrm{M}$ & $16 \mathrm{M}$ & $18 \mathrm{M}$ \\
\cline { 2 - 7 } & $8 \mathrm{M}$ & $10 \mathrm{M}$ & $12 \mathrm{M}$ & 33.09 & 35.29 & 31.57 \\
\cline { 2 - 7 } & 21.22 & 30.12 & 31.22 & 40.73 & 47.92 & 41.69 \\
\hline 0.35 & 27.46 & 36.13 & 37.21 & 34.47 & 43.20 & 37.23 \\
\hline 0.40 & 26.16 & 33.10 & 34.09 & 29.68 & 39.23 & 33.35 \\
\hline 0.45 & 25.52 & 27.80 & 29.07 & 22.85 & 26.88 & 23.39 \\
\hline 0.50 & 21.15 & 26.83 & 28.66 & 17.87 & 21.02 & 18.29 \\
\hline 0.55 & 19.27 & 25.35 & 26.11 & 16.08 & 18.92 & 16.46 \\
\hline 0.60 & 16.79 & 22.09 & 22.75 & 14.25 & 16.77 & 14.59 \\
\hline 0.65 & 15.82 & 20.81 & 21.43 & 19.49 & 14.20 & 12.35 \\
\hline 0.70 & 14.38 & 18.92 & 19.49 & 12.07 & 12.82 & 11.15 \\
\hline 0.75 & 13.00 & 17.11 & 17.62 & 10.90 & 11.01 & 9.58 \\
\hline 0.80 & 12.66 & 16.66 & 17.16 & 9.36 & 10.90 & 9.48 \\
\hline 0.85 & 11.42 & 15.02 & 15.47 & 9.27 & & \\
\hline 0.90 & & & & & & \\
\hline
\end{tabular}

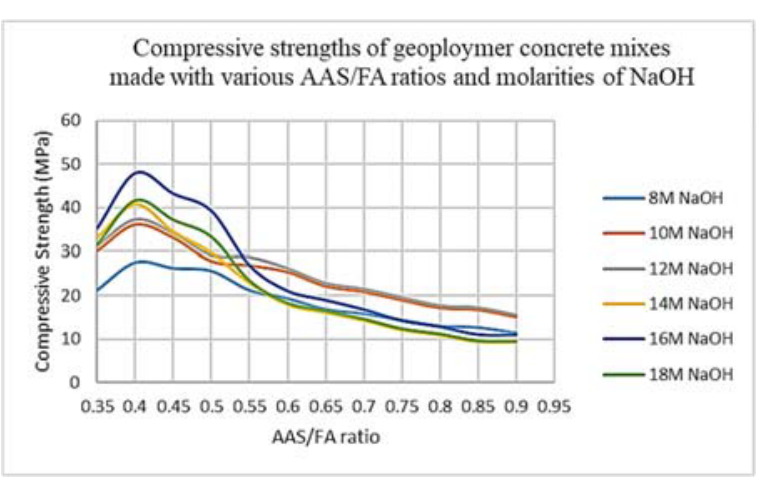

Fig.1. Compressive strength for various GPC mixes made with different molarities of $\mathrm{NaOH}$ and for various Alkali Activator solution (AAS) / Fly ash (FA) ratios

In the present study, geopolymer concrete mixes are developed and the effect of temperature and period of heat curing is also studied and found that the optimum temperature for curing is $60^{\circ} \mathrm{C}$ and optimum period of curing is $24 \mathrm{~h}$ based on the compressive strengths achieved. So, this study confirms that beyond $24 \mathrm{~h}$ period, heat curing is not required.

In the current study, geopolymer concrete mixes are oven cured at three different temperatures for $30^{\circ} \mathrm{C}$, $60^{\circ} \mathrm{C}$ and $90^{\circ} \mathrm{C}$ for various periods of curing such as $12 \mathrm{~h}, 24 \mathrm{~h}, 48 \mathrm{~h}, 72 \mathrm{~h}$ and $96 \mathrm{~h}$.

Table 2. Effect of temperature and period of heat curing on compressive strength

\begin{tabular}{|c|c|c|c|}
\hline \multicolumn{4}{|c|}{ Compressive Strength (MPa) } \\
\hline & $\begin{array}{c}30^{\circ} \mathrm{C} \text { Oven } \\
\text { curing }\end{array}$ & $\begin{array}{c}60^{\circ} \mathrm{C} \text { Oven } \\
\text { curing }\end{array}$ & $\begin{array}{c}90^{\circ} \mathrm{C} \text { Oven } \\
\text { curing }\end{array}$ \\
\hline $12 \mathrm{~h}$ & 15.54 & 24.67 & 25.01 \\
\hline $24 \mathrm{~h}$ & 30.19 & 47.92 & 48.16 \\
\hline $48 \mathrm{~h}$ & 30.36 & 48.19 & 48.64 \\
\hline
\end{tabular}

\begin{tabular}{|c|c|c|c|}
\hline $72 \mathrm{~h}$ & 30.38 & 48.22 & 48.67 \\
\hline $96 \mathrm{~h}$ & 30.88 & 49.02 & 49.49 \\
\hline
\end{tabular}

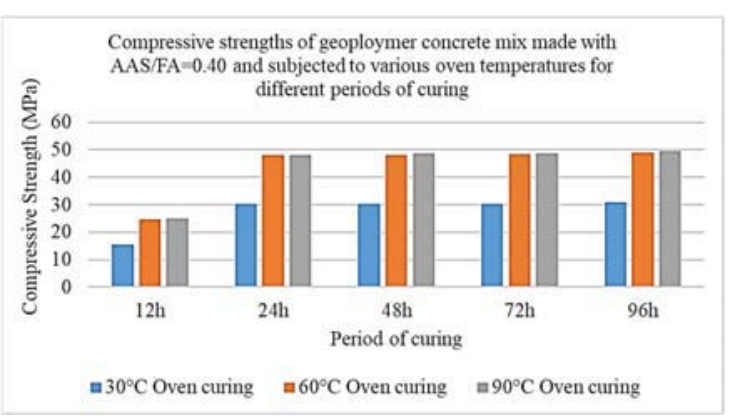

Fig 2. Effect of temperature and period of heat curing on compressive strength

It is observed that the compressive strength increases as temperature of oven curing increases from $30^{\circ} \mathrm{C}$ to $90^{\circ} \mathrm{C}$ and also with the period of curing from $12 \mathrm{~h}$ to $96 \mathrm{~h}$. The optimum combination of temperature $60^{\circ} \mathrm{C}$ and period of curing $24 \mathrm{~h}$ is chosen as there is no significant improvement of compressive strength is observed beyond $60^{\circ} \mathrm{C}$ temperature and $24 \mathrm{~h}$ period of oven curing. So, it can be recommended that beyond $24 \mathrm{hrs}$ period, heat curing is not required.

\section{Factors affecting Initials setting times}

Data procured from previous studies is:

- $16 \mathrm{M} \mathrm{NaOH}$

- $\mathrm{SiO}_{2} / \mathrm{Na}_{2} \mathrm{O}=2.0$ in $\mathrm{Na}_{2} \mathrm{SiO}_{3}$

- $\mathrm{Na}_{2} \mathrm{SiO}_{3} / \mathrm{NaOH}=2.5$ by mass

Sodium hydroxide solution is prepared before $24 \mathrm{hrs}$. Sodium silicate solution and sodium hydroxide solutions are mixed before 30 minutes of making powder paste. Use of FA alone will not set the GPC 
immediately after casting. Initial setting of geopolymer concrete made with fly ash alone is very high, no setting is observed even after 2 days of casting making demoulding process delayed. So ground granulated blast furnace slag (GGBS) is added to reduce the setting time.

Table 3. Effect of GGBS on the initial setting time

\begin{tabular}{|c|c|}
\hline Type & Initial Setting time(min) \\
\hline GPC made with FA & 2889 \\
\hline $\begin{array}{l}\text { GPC made with } \\
\text { FA+15\%GGBS }\end{array}$ & 193 \\
\hline $\begin{array}{l}\text { GPC made with } \\
\text { FA+25\%GGBS }\end{array}$ & 101 \\
\hline $\begin{array}{l}\text { GPC made with } \\
\text { FA+50\%GGBS }\end{array}$ & 34 \\
\hline
\end{tabular}

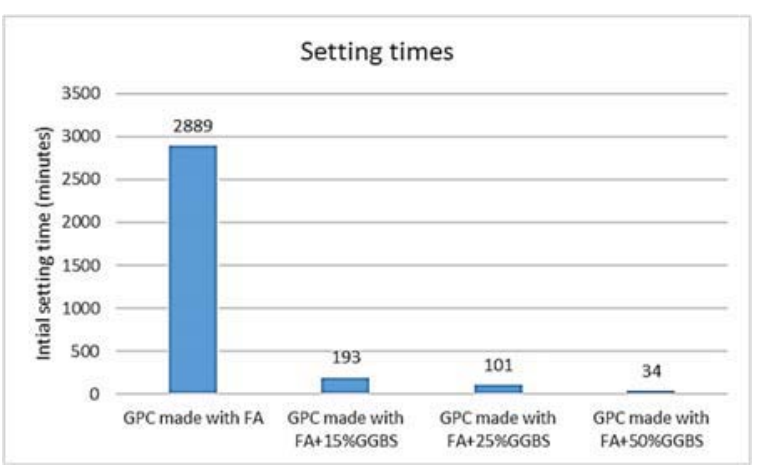

Fig. 3. Effect of GGBS on the initial setting time

Table 4. Effect of $\mathrm{NaOH}$ molarity on the setting times

\begin{tabular}{|c|c|c|c|c|c|c|c|}
\hline \multirow{3}{*}{$\begin{array}{c}\text { GPC made with } \\
\text { FA+50\%GGBS }\end{array}$} & $\begin{array}{c}\text { Setting } \\
\text { times } \\
\text { (minutes) }\end{array}$ & $8 \mathrm{M}$ & $10 \mathrm{M}$ & $12 \mathrm{M}$ & $14 \mathrm{M}$ & $16 \mathrm{M}$ & $18 \mathrm{M}$ \\
\cline { 2 - 8 } & Initial & 143 & 111 & 89 & 55 & 34 & 23 \\
\cline { 2 - 8 } & Final & 1879 & 1567 & 1243 & 990 & 556 & 435 \\
\hline
\end{tabular}

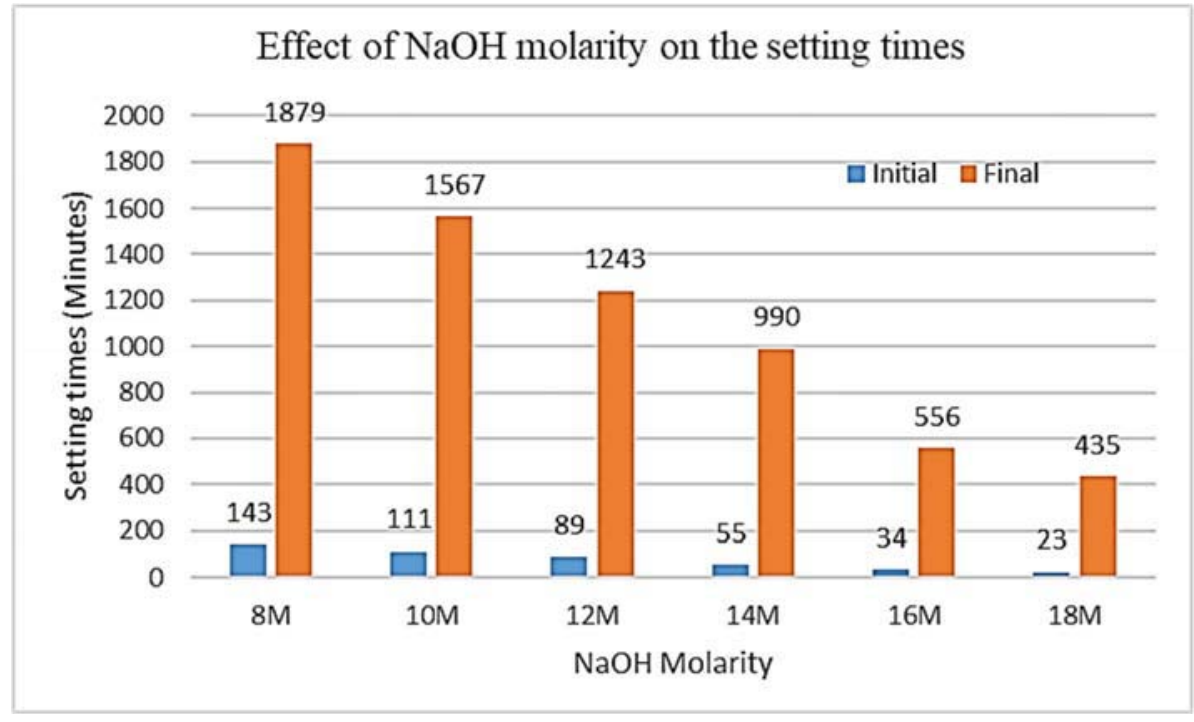

Fig.4. Effect of $\mathrm{NaOH}$ molarity on the setting times

The increase of sodium hydroxide molarity decreases the initial and final setting times. $\mathrm{NaOH}$ concentration is a main reason for leaching out of $\mathrm{Si}_{4}{ }^{+}$and $\mathrm{Al}_{3}{ }^{+}$ions from fly ash; therefore, the time of setting tends to increase with the decrease in the molarity of $\mathrm{NaOH}$

If fly ash alone is used then it is suggested to seal the concrete moulds and keep it in oven with the moulds. So, rest period in the case of fly ash based geopolymer is zero otherwise if GGBS is added to fly ash then the rest period may vary from 1- 3 days and keep in oven without seal after demoulding. Many researchers reported that the addition of silica fume and GGBS may decrease the setting times of geopolymer concrete drastically and lets the concrete set quickly due to formation of additional strength imparting products based on calcium content available in GGBS.

\section{Conclusions}

Based on the studies made following conclusions are arrived at-

1. Alkali Activator solution (AAS) / Fly ash (FA) ratio $=0.40$ yields highest compressive strength for $16 \mathrm{M} \mathrm{NaOH}$ with $\mathrm{Na}_{2} \mathrm{SiO}_{3} / \mathrm{NaOH}=2.5$ and $\mathrm{SiO}_{2} / \mathrm{Na}_{2} \mathrm{O}=2.0$. 
2. The optimum combination of temperature $60^{\circ} \mathrm{C}$ and period of curing $24 \mathrm{~h}$ is chosen as there is no significant improvement of compressive strength is observed beyond $60^{\circ} \mathrm{C}$ temperature and $24 \mathrm{~h}$ period of oven curing. So, it can be recommended that beyond $24 \mathrm{hrs}$ period, heat curing is not required.

3. Initial setting of geopolymer concrete made with fly ash alone is very high, no setting is observed even after 2 days of casting making demoulding process delayed. So ground granulated blast furnace slag (GGBS) is added to reduce the setting time

4. The increase of sodium hydroxide molarity decreases the initial and final setting times. $\mathrm{NaOH}$ concentration is a main reason for leaching out of $\mathrm{Si}_{4}{ }^{+}$and $\mathrm{Al}_{3}{ }^{+}$ions from fly ash; therefore, the time of setting tends to increase with the decrease in the molarity of $\mathrm{NaOH}$

5. Many researchers reported that the addition of silica fume and GGBS may decrease the setting times of geopolymer concrete drastically and lets the concrete set quickly due to formation of additional strength imparting products based on calcium content available in GGBS.

\section{References}

1. Srinivas. T, Abhignya. G and Ramana Rao. N.V, A Review on Geopolymer RCC Beams made with Recycled Coarse Aggregate, E3S Web of Conferences, ICMED, 10-12 July 2020, India (2020).

2. T. Srinivas, S. V. Srinidhi and N.V. Ramana Rao, A Review on Flexural Behavior of RCC Beams Made with Geopolymer Concrete, E3S Web of Conferences, ICMED, 10-12 July 2020, India (2020).

3. T. Srinivas , P. Bhavana, and N. V. Ramana Rao, Effect of Manufactured Sand on Flexural Behavior of Geopolymer RCC Beams: A review, E3S Web of Conferences, ICMED, 10-12 July 2020, India (2020).

4. Srinivas Rao J, S K Tummala, Kuthuri N R, Indonesia Journal of Electrical Engg. \& Computer Science, 21 (723), 2020

5. T. Srinivas and N.V.Ramana Rao, IJCIET, Volume 10, 510 (2019).

6. K. Sai Gopi, Dr. T. Srinivas and S. P. Raju V, E3S Web of Conferences ICMED 184, 01084GRIET, 28-29

February, https://doi.org/10.1051/e3sconf/2020184011084(20 20)

7. Jagannadha Kumar, M.V., Jagannadha Rao, K., Dean Kumar, B., Srinivasa Reddy, V., Int. J. of Civil Eng. and Tech., 9(7), pp. 1133-1141 (2018)

8. A.U. Haq, A. K. Kavit, T. Rao, T. Buddi, D. Baloji, K. Satyanarayana, S. K. Singh, Materials Today: Proceedings, 18, 4589 (2019)

9. Ganta, J.K., Seshagiri Rao, M.V., Mousavi, S.S.,
Srinivasa Reddy, V., Bhojaraju, C., Structures 28, pp. 956-972 (2020)

10. Naidu, K.S.S.T., Rao, M.V.S., Reddy, V.S., Int. J. of Innov. Tech. and Explor. Eng.g (IJITEE), 8(9 Special Issue 2), pp. 641-642 (2019)

11. B. J. Varghese and P. B. Bobba, " 2016 IEEE 1st International Conference on Power Electronics, Intelligent Control and Energy Systems (ICPEICES), 2016, pp. 1-5

12. Chandana Priya, C., Seshagiri Rao, M.V., Srinivasa Reddy, V., Int. J. of Civil Eng. and Tech., 9(11), pp. 2218-2225 (2018)

13. Satya Sai Trimurty Naidu, K., Seshagiri Rao, M.V., Srinivasa Reddy, V., Int. J. of Civil Eng. and Tech., 9(11), pp. 2383-2393 (2018)

14. Supriya, Y., Srinivasa Reddy, V., Seshagiri Rao, M.V., Shrihari, S., Int. J. of Rec. Tech. and Engi., 8(3), pp. 5381-5385 (2019)

15. Kotkunde, N., Krishna, G., Shenoy, S.K., Gupta, A.K., Singh, S.K. International Journal of Material Forming, 10 (2), pp. 255-266 (2017)

16. Govardhan, D., Kumar, A.C.S., Murti, K.G.K., Madhusudhan Reddy, G. Materials and Design, 36, pp. 206-214. (2012)

17. Kumar, P., Singhal, A., Mehta, S., Mittal, A. Journal of Real-Time Image Processing, 11 (1), pp. 93-109. (2016)

18. M. Kavitha, P. B. Bobba and D. Prasad, 2016 7th India International Conference on Power Electronics (IICPE), 2016, pp. 1-6

19. Raghunadha Reddy, T., Vishnu Vardhan, B., Vijayapal Reddy, P. International Journal of Applied Engineering Research, 11 (5), pp. 3092-3102 (2016)

20. Hussaini, S.M., Krishna, G., Gupta, A.K., Singh, S.K. Journal of Manufacturing Processes, 18, pp. 151-158 (2015) 